UDC 615.2

DOI: $10.15587 / 1729-4061.2022 .253555$

\title{
THE ANALGESIC AND ANTI-INFLAMMATORY EFFECT OF LAWSONE ISOLATED FROM LAWSONIA INERMIS
}

\author{
Tayseer Ali Talab, Narjes Alfuraiji, Ali Esmail Al-Snafi
}

This study aimed to assess the analgesic and anti-inflammatory effects of lawsone isolated from henna leaves (Lawsonia inermis).

Methods: A total of 120 healthy adult mice (weighing about $25 \pm 5$ g) were included in this study. Sixty mice out of the total were used to determine $L D_{50}, 30$ mice to determine the anti-inflammatory test, and the remaining (30 mice) were used for an analgesic test. The hot plate was used to determine the analgesic effect, while the anti-inflammatory effect was determined by the ability of the compound to minimize the inflammation and edema caused by the injection of carrageenan.

Results: Lawsone was isolated from Lawsonia inermis. A Stuart SMP10 digital melting point apparatus was used for measuring all melting points. Infrared spectrometer FT-IR 400D was used for measuring/recording IR spectra (KBr) which the frequency of absorption was represented as $\mathrm{cm}^{-1}$. For $1 H$-NMR spectrum recording, a Brukspectrophotometer of $400 \mathrm{MHz}$ was used with internal TMS standard, with deuterated Ś 2.51 ppm for acetone-d6, remained solvent signals as well as 13C.NMR was used. TLC was utilized as adsorbent, UV light, or iodine-completed visualization to verify compounds' purities.

The $L D_{50}$ of the oral lawsone was $96 \mathrm{mg} / \mathrm{kg}$, and the highest dosage that did not kill any of the experimental animals was $80 \mathrm{mg} / \mathrm{kg}$, which was used to investigate lawsone's analgesic and anti-inflammatory effects.

Lawsone and aspirin possessed an analgesic effect compared to the control group $(p<0.0001$ and $p<0.001$, respectively); however, lawsone induced a potent analgesic effect compared to aspirin ( $p<0.1)$. In contrast, Lawsone and aspirin exerted an anti-inflammatory effect $(p<0.05)$ compared to the control group and were equipotent in carrageenaninduced hind paw edema.

Conclusion: It is concluded that lawsone possesses analgesic and anti-inflammatory effects, which endorse the practical medical importance of Lawsonia inermis. The latter is widely used traditionally for these purposes own to its costeffectiveness and safety; however, further studies are required to determine the systemic safety of lawsone

Keywords: Lawsone, Lawsonia inermis, henna, analgesic, anti-inflammatory, medicinal plants, phytotherapy, herb, pharmacognosy, pharmacology

How to cite:

Talab, T. A., Alfuraiji, N., Al-Snafi, A. E. (2022). The analgesic and anti-inflammatory effect of Lawsone isolated from Lawsonia Inermis. ScienceRise: Pharmaceutical Science, 1 (35), 77-84. doi: http://doi.org/10.15587/1729-4061.2022.253555

(C) The Author(s) 2022

This is an open access article under the Creative Commons CC BY license hydrate

\section{Introduction}

Lawsonia inermis Linn (Family: Lythraceae) is a plant often known as henna, predominant in tropical and subtropical regions and has been extensively investigated and used worldwide in traditional medicine and as cosmetic. It has been used as a dye for over 9000 years for its cosmetic value. However, it is used traditionally as abortifacients to treat gonorrhea, intestinal amebiasis, headache, sore throat (decoction), as a blood tonic, hair tonic and treats dandruff and scalp disorders for Jaundice, skin disorders, fever, malaria, conjunctivitis, pimples, and scabies [1]. Lawsonia inermis Linn is a native of both Africa and Asia. Furthermore, henna is distributed in Egypt, Africa, Ethiopia, Sudan, Somalia, Niger, Zaire, Burkina Faso, Benin, Gambia, Cote D'Ivoire, Ghana, Togo, South Africa, Guinea-Bissau, Guinea, Sierra Leone, Mali, Senegal, Liberia, Comoros, Nigeria, Seychelles as well as in Asia (Pakistan, Sri Lanka, India).
Henna is commonly grown in tropical areas, including North and East Africa, the Arabian Peninsula, the Middle East's southern regions, and South Asia [2, 3].

Lawsonia inermis contained of phenolic, flavonoids, saponins, proteins, carbohydrates, xanthones, fat, resin, and tannins, alkaloids, terpenoids, quinones, coumarins, adding to 2-hydroxy-1,4-naphthoquinone (lawsone, which is the main active component of the henna plant) and several alkaloids, phenolics, naphthoquinone derivatives, and flavonoids were isolated from Lawsonia inermis's flower, root, bark, and leaves, all of which have been shown to have active compounds $[4,5]$.

The pharmacological studies on Lawsonia inermis revealed antibacterial activity [6, 7], antifungal [8, 9], antiparasitic [10,11], molluscicidal [12], antioxidant [13, 14], hepatoprotective [15, 16], central nervous [17], analgesic [18, 19], anti-inflammatory [20, 21], antipyretic [18], wound [22, 23] and burn healing [24], immuno- 
modulatory [25, 26], anti-urolithiatic [27, 28], antidiabetic and hypolipidemic [29, 30], antiulcer [31], antidiarrhoeal [19], diuretic [32], anticancer [33, 34] and many other pharmacological effects.
This study was designed to isolate lawsone from henna leaves and investigate its analgesic and antiinflammatory effects using mice as an experimental model.

\section{Planning (Methodology) of the research}

The methodology was designed as per Fig. 1 to achieve the research aim.

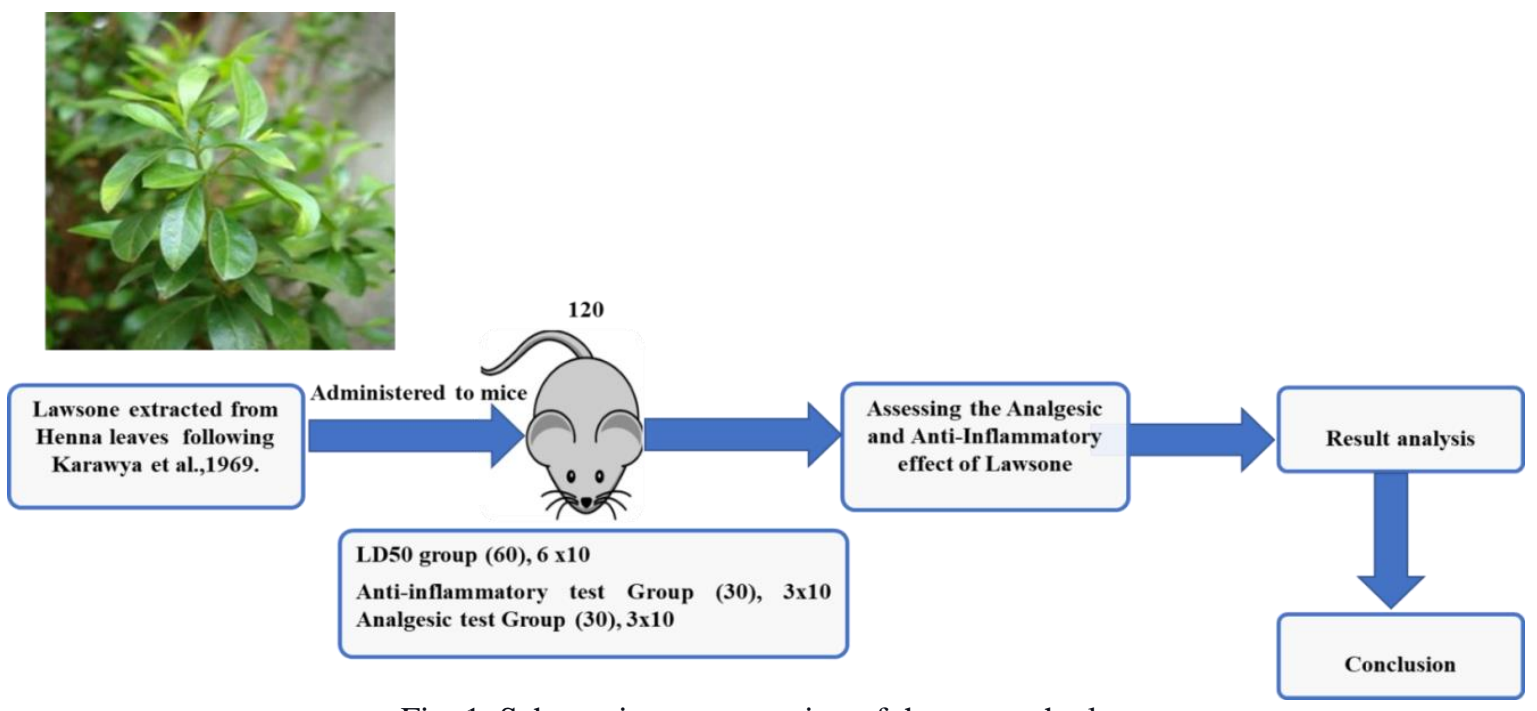

Fig. 1. Schematic representation of the research plan

\section{Materials and methods}

\section{Chemicals}

Lawsone, carrageenan, chloroform, methanol, benzene, ethyl acetate, ammonium hydroxide, and anhydrous sodium carbonate were obtained from Aldrich (Sigma - Aldrich, Germany).

\section{Animals}

A total of 120 healthy adult mice (weighing about $25 \pm 5 \mathrm{~g}$ ) were obtained from the laboratory animal house, College of Science, University of Thi-Qar. The study was carried out in the College of Medicine, Thi-Qar university from January to August 2021. Animals were housed in polyacrylic cages and kept under standard laboratory conditions (natural light/dark cycle, RT $22 \pm 3^{\circ} \mathrm{C}$ ). Animals were fed a dry rat pellet diet, and tap water was provided ad libitum. Thi-Qar university animal ethics committee approved the experimental protocol. Sixty mice were used to determine $\mathrm{LD}_{50}$ and 30 mice for the anti-inflammatory test and 30 for an analgesic test. The animal ethics committee supervised by the Institute for the Prevention of Cruelty to Animals and the Research Council reviewed and approved the current study, and Thi-Qar university's animal ethics committee approved the experimental protocol (456/1Q) 24.11.2020. The European Council Directive recommendations (2010/63/EU) on September 22, 2010, amended by Regulation (EU) 2019/1010, on standards to protect animals used experimentally were also followed.

\section{Extraction of lawsone}

The leaves of locally grown henna (Southern Iraq, classified by the specialist in the Biology DepartmentPlant Taxonomy, College of Education, Thi-Qar University) were dried and powdered. One $\mathrm{kg}$ of plant leaf powder was extracted for 8 hours with 5 litters of water saturated with anhydrous sodium carbonate. The extract was filtered and was acidified with $1 \mathrm{~N} \mathrm{HCl}$ to $\mathrm{pH} 3$. The lawsone was taken by liter of chloroform, and a separation funnel separated the chloroform and this process. Then the chloroform extract was dried with a rotary evaporator $\left(30{ }^{\circ} \mathrm{C}\right)$, and the lawsone was purified by recrystallization with (methanol: benzene 1:1).

\section{Purification of pigment by chromatography}

The residue was shaken in "Solvent A", a mixture of ethyl acetate, methanol, and ammonium hydroxide $(5: 15: 60)$. The precipitated lawsone was collected on filter paper and purified using a $50 \times 2.5 \mathrm{~cm}$ column of silica gel with a mesh size of 60 . Before packing, the silica gel was shaken for $1-2 \mathrm{hrs}$ in the solvent " $\mathrm{A}$ " in a beaker, and the column was left for $12-15 \mathrm{hrs}$ to equilibrate. A $0.5 \mathrm{~g}$ sample in $1 \mathrm{ml}$ of solvent (A) was run through the column, and $0.5 \mathrm{ml}$ effluents were collected at a $1 \mathrm{ml} / \mathrm{min}$ flow rate. Flash Chromatography apparatus was used to separate Lawsone. The latter was identified using 2-dimension TLC in solvents A compared to known lawsone. [35].

\section{Characterization of isolated Lawsone}

A Stuart SMP10 digital melting point apparatus was used for measuring all melting points. Infrared spectrometer FT-IR 400D was used for measuring/recording IR spectra $(\mathrm{KBr})$ which the frequency of absorption was represents as $\mathrm{cm}^{-1}$. For $1 \mathrm{H}-\mathrm{NMR}$ spectrum recording, a Bruk-spectrophotometer of $400 \mathrm{MHz}$ was used with internal TMS standard, with deuterated Ś $2.51 \mathrm{ppm}$ for aceton-d6 remained solvent signals as well as 13C.NMR was used. TLC was utilized as adsorbent, UV light or iodine-completed visualization for verifying purities of compounds [36].

\section{Determination of $\mathbf{L D}_{\mathbf{5 0}}$}

The $\mathrm{LD}_{50}$ of lawsone (100, 200, 400, 800, 1600 , and $3200 \mathrm{mg} / \mathrm{kg}$ ) was performed in mice (6 groups, 
10 each) as mentioned by Raj et al., 2013 and Al-Ali et al., 2008 [37, 38].

\section{The anti-inflammatory and analgesic tests}

The group of the anti-inflammatory test (30 mice) was divided into 3 subgroups. The first one was given normal saline to serve as a control, while the second and third groups were administered with lawsone $(80 \mathrm{mg} / \mathrm{kg}$ ) and aspirin $200 \mathrm{mg} / \mathrm{kg} \mathrm{BW}$ (both as single oral dose), 60 minutes before the test. A localized inflammation was induced in all the three subgroups by injecting carrageenan $(25 \mu \mathrm{l}, 2 \%$ in saline) subcutaneously into the plantar surface of the right hind paw, and the hind paw edema (thickness) induced by carrageenan $(\mathrm{mm})$ was determined half an hour later. The second group was divided and treated in the same manner. The hot plate test was used to determine the analgesic effect of lawsone and aspirin after 60 minutes. The mouse hot plate analgesic assay tests painful stimulation from heat sensitivity. The temperature of the hot plate was maintained at $55^{\circ} \mathrm{C}$.
Responses such as jumping, the paws' withdrawal, and the paws' licking were observed. The time (latency period) when animals were placed and until responses occurred was recorded by the stopwatch and considered the analgesic period $[39,40]$.

Statistical methods. The Student t-test was applied to investigate the significance among the groups (SPSS 12.0 software, USA).

\section{Results}

The UV, FTIR, 1H NMR, and 13C.NMR- spectroscopy techniques were used for the structural characterization. UV $\max$ at $273-325 \mathrm{~nm}$ for the same compound indicates conjugation (Fig. 2). The peak detected at 1413 and $1471 \mathrm{~cm}-1$ indicates of $\mathrm{C}=\mathrm{C}$ in the IR spectra. The peak at $1616 \mathrm{~cm}^{-1}$ indicated the presence of a carbonyl group and a stretching absorption band at $3380 \mathrm{~cm}^{-1}$ corresponding to the vibration of the related $\mathrm{O}-\mathrm{H}$ bond (Fig. 3).

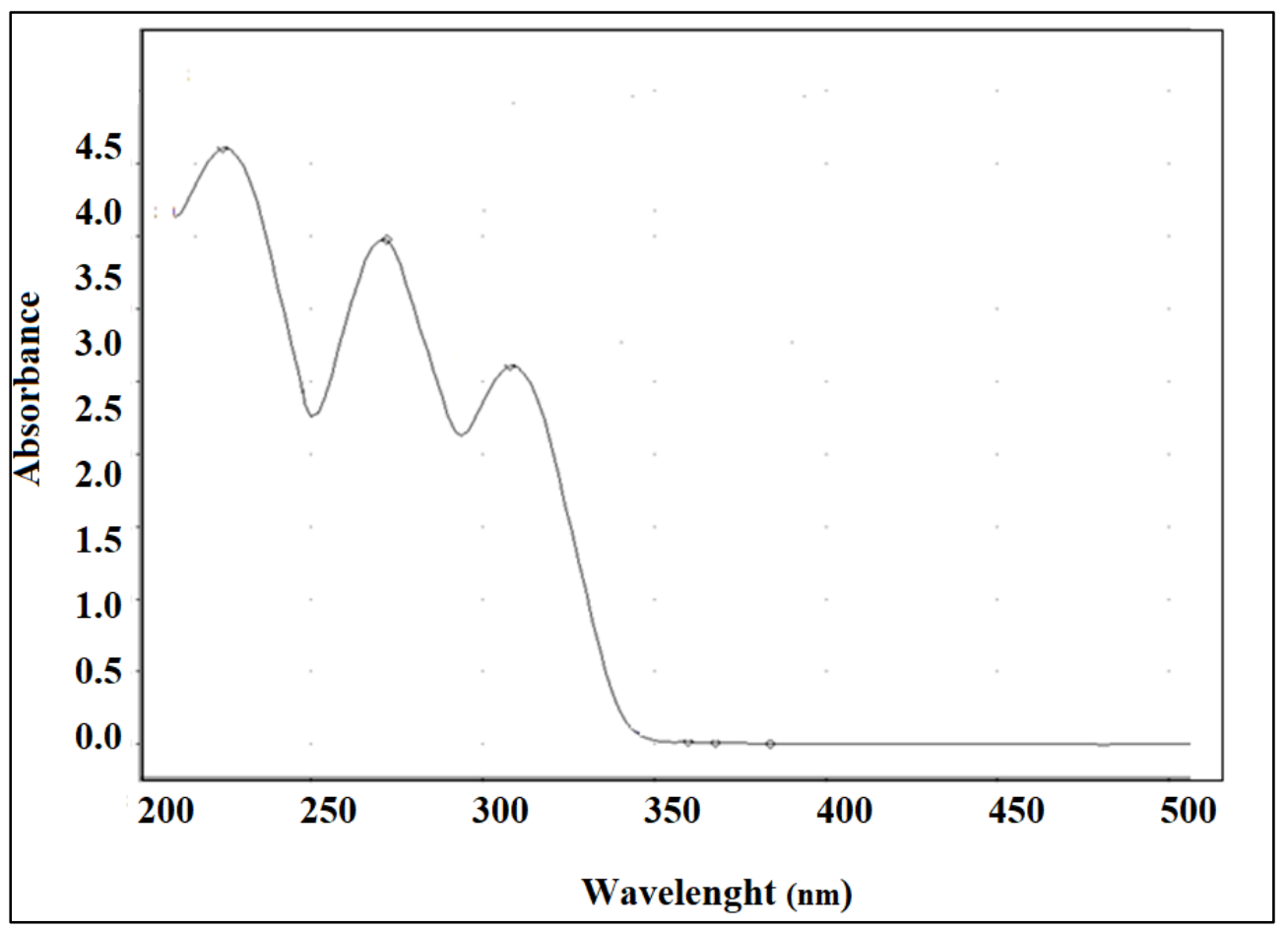

Fig. 2. Shows UV Spectral analysis of the isolated lawsone

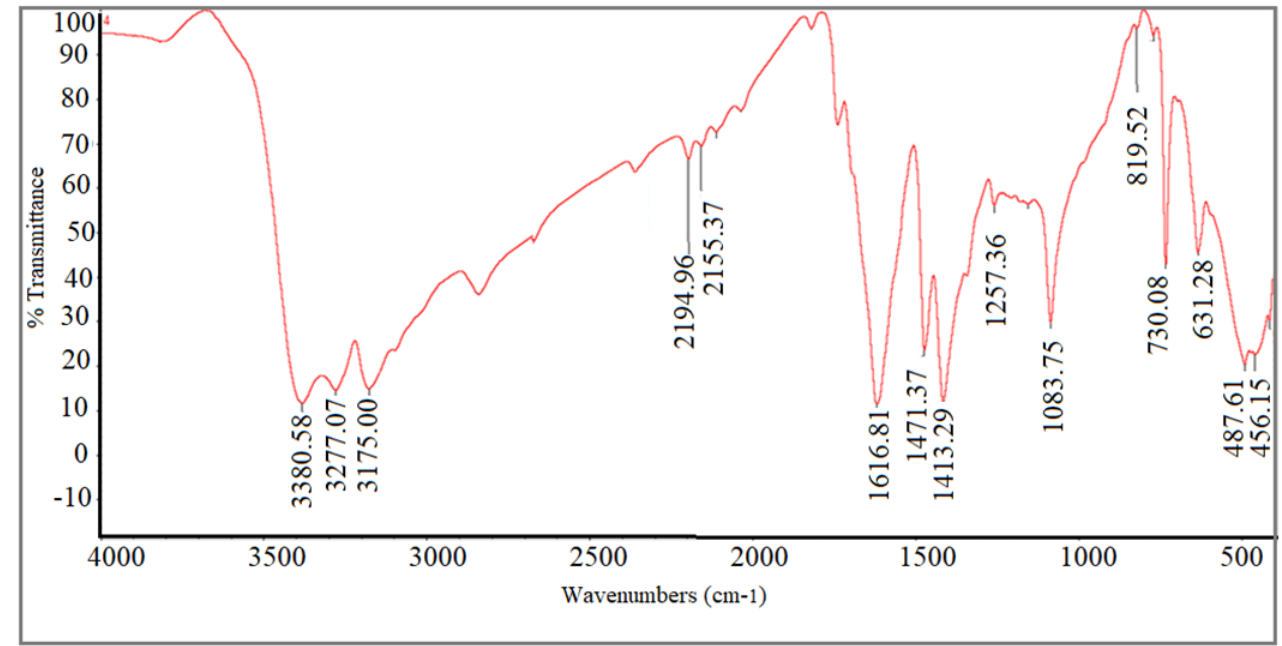

Fig. 3. FT-IR Spectral analysis of isolated lawsone 
In the ${ }^{1} \mathrm{H}-\mathrm{NMR}$ spectrum (Fig 4), the singlets at 2.04 and 2.84 are refer to the solvent (aceton-d6). The singlet at $6.35(1 \mathrm{H}, \mathrm{s})$ refers to the proton attached to carbon $3(3 \mathrm{C}-\mathrm{H})$. The signal at 7.19-7.57 $(3 \mathrm{H}, 1.3 \mathrm{~Hz})$ for (7C-H) appeared as doublet of triplet with $J=7.8$ was assigned to $(7 \mathrm{C}-\mathrm{H})$. Also, presence of doublet of triplet $7.70(\mathrm{td}, J=7.8,1.3 \mathrm{~Hz})$ was assigned to $(6 \mathrm{C}-\mathrm{H})$. The signals at $8.18(\mathrm{ddd}, J=7.8,1.3 \mathrm{~Hz})$ and $8.20(1 \mathrm{H}$, ddd,
$0.5 \mathrm{~Hz})$, corresponding to $(5 \mathrm{C}-\mathrm{H})$ and $(8 \mathrm{C}-\mathrm{H})$ respectively. Based on spectral data, the compound was identified as lawsone.

The ${ }^{13}$ C.NMR spectra (Fig. 5) was also identified a lawsone structure. Moreover, Fig. 6 shows the values of each carbon atoms. This data (UV, FT-IR, ${ }^{1}$ H.NMR and ${ }^{13}$ C.NMR) were found to clearly identified and conformed the lawsone structure.

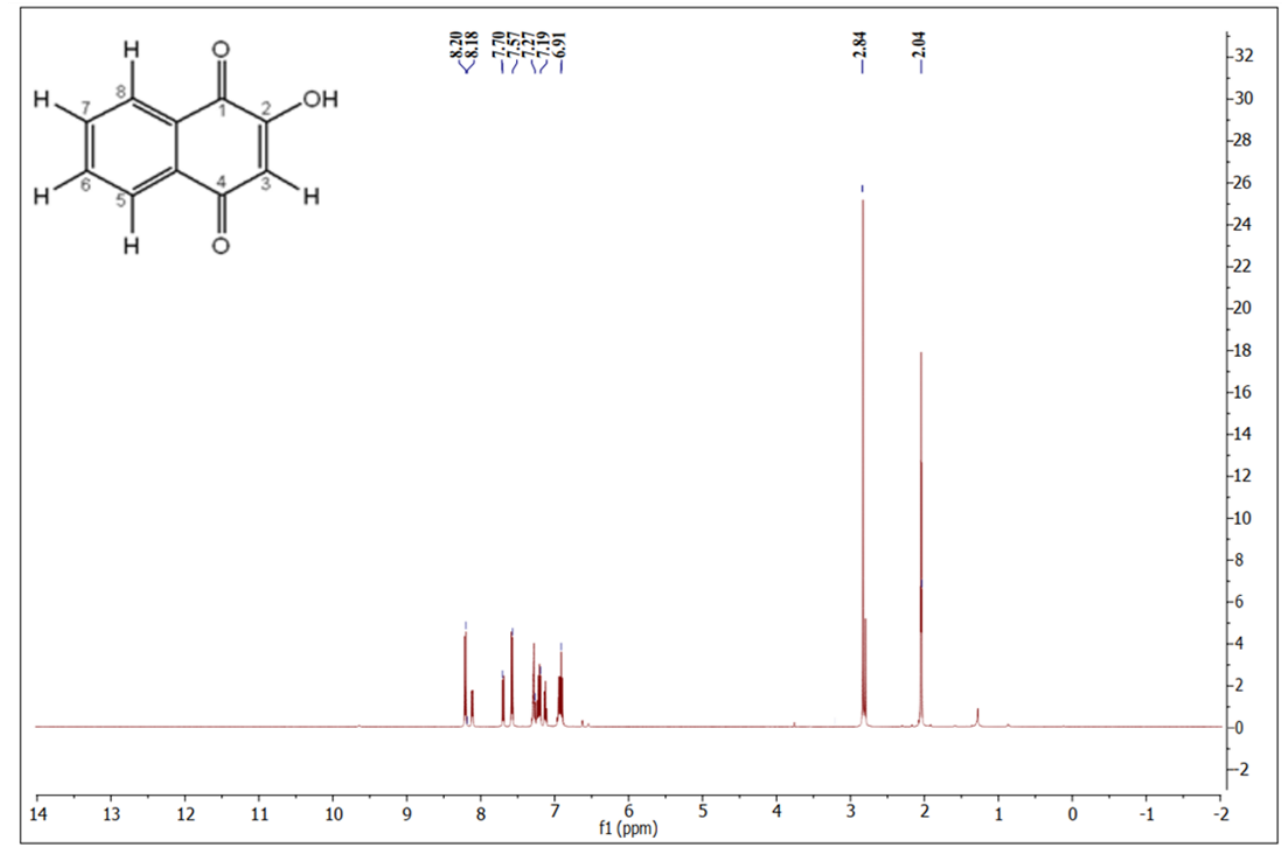

Fig 4. ${ }^{1}$ H.NMR Spectral analysis of isolated lawsone

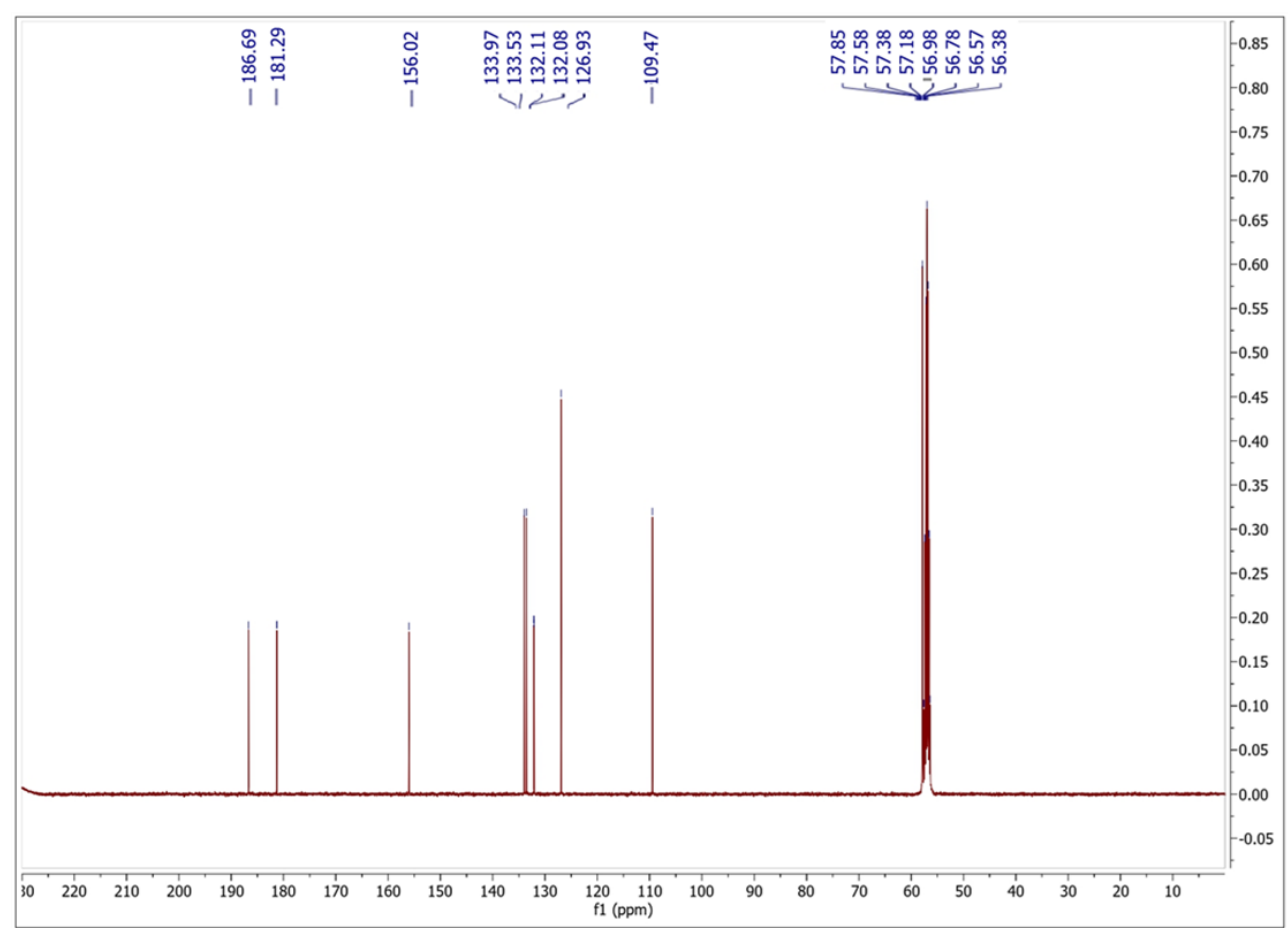

Fig 5. ${ }^{13}$ C.NMR Spectral analysis of isolated lawsone 


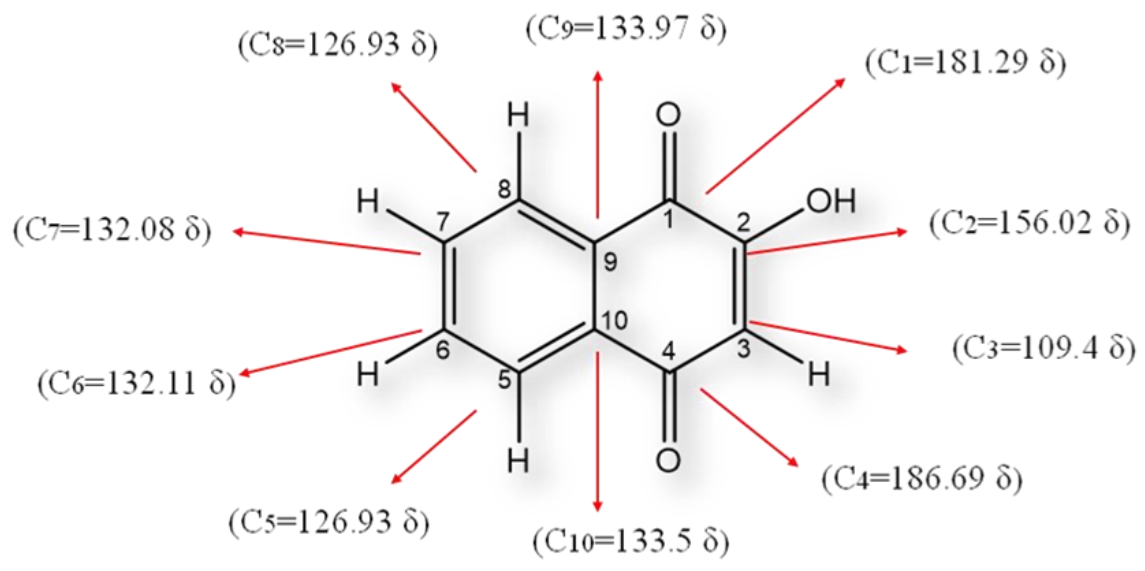

Fig $6 .{ }^{13}$ C.NMR Positions for isolated lawsone

Lawsonia inermis leaves contained $1.2 \%$ of lawsone, its melting point was $193 \mathrm{C}$. Both the extracted and standard lawsone showed Rf of 0.58 on TLC. The mixture of the extracted and standard lawsone gave one spot with the same $\mathrm{R}_{\mathrm{f}}$ of the standard lawsone on TLC.

The $\mathrm{LD}_{50}$ of the oral lawsone in mice was $96 \mathrm{mg} / \mathrm{kg}$. The highest dosage that did not kill any of the experimental animals was $80 \mathrm{mg} / \mathrm{kg}$.

Both lawsone and aspirin possessed an analgesic effect compared to the control group ( $<<0.0001$ and $\mathrm{p}<0.001$, respectively). However, lawsone induced potent analgesic effect compared with aspirin as determine by the time of analgesic period recorded in hot plate model $(\mathrm{p}<0.1)$ (Table 1).

Table 1

The analgesic effect of lawsone in comparison with aspirin and control groups

\begin{tabular}{|c|c|c|}
\hline Groups & $\begin{array}{c}\text { The period of } \\
\text { analgesia }\end{array}$ & Significancy \\
\hline Control & $6.20 \pm 0.26$ & \multirow{3}{*}{$\begin{array}{l}\text { Lawsone vs Control } \\
\mathrm{p}<0.0001 \\
\text { Aspirin vs Control } \mathrm{p}<0.01 \\
\text { Lawsone vs Aspirin } \\
\mathrm{p}<0.1\end{array}$} \\
\hline Lawsone & $23.50 \pm 0.57$ & \\
\hline Aspirin & $9.75 \pm 1.70$ & \\
\hline
\end{tabular}

On the other hand, both lawsone and aspirin exert anti-inflammatory effect $(\mathrm{p}<0.05)$ compared with control group. They were equipotent in carrageenan induced hind paw oedema (Table 2).

Table 2

Effect of lawsone on hind paw oedema (thickness) induced by carrageenan $(\mathrm{mm})$ compared with aspirin and control group

\begin{tabular}{|c|c|c|}
\hline Groups & $\begin{array}{l}\text { Inhibition of hind } \\
\text { paw oedema (thick- } \\
\text { ness) induced by } \\
\text { carrageenan (mm) }\end{array}$ & Significancy \\
\hline Control & $1.53 \pm 0.43$ & \multirow{3}{*}{$\begin{array}{l}\text { Lawsone vs Control } \\
\mathrm{p}<0.05 \\
\text { Aspirin vs Control } \\
\mathrm{p}<0.05 \\
\text { Lawsone vs Aspirin } \\
\text { Not significant }\end{array}$} \\
\hline Lawsone & $1.20 \pm 0.10$ & \\
\hline Aspirin & $1.13 \pm 0.25$ & \\
\hline
\end{tabular}

\section{Discussion}

Our study revealed that the lawsone content in henna leaves was $1.2 \%$, slightly higher than some researchers indicated $[35,40]$. The melting point of lawsone in our study was $193^{\circ} \mathrm{C}$. It lies within the melting range of ozone $192-195^{\circ} \mathrm{C}$. The $\mathrm{Rf}$ of the extracted lawsone in this study was 0.58 , like that recorded by Karawya et al. (0.57) when using the same solutions [41].

The highest safe dose of lawsone produced an analgesic effect more potent than aspirin, but resulted in a similar anti-inflammatory effect. Many studies showed that Lawsonia inermis possessed anti-inflammatory and analgesic effects.

In rats, the raw ethanolic extract of Lawsonia inermis $(0.25-2.0 \mathrm{~g} / \mathrm{kg})$ had substantial analgesic, antiinflammatory, and antipyretic effects that were dose dependent. Crude extracts appeared to have less potent analgesic, antipyretic, and anti-inflammatory effects than chloroform and butanol fractions, with butanolic extract $(500 \mathrm{mg} / \mathrm{kg})$ shown more effective in the analgesia tests. Methanolic extract of Lawsonia inermis also showed peripheral and central analgesic, antipyretic and antiinflammatory activity in rats [42].

The analgesic, anti-inflammatory, and antipyretic activity of a pure compound isolated from the chloroform extract (2-hydroxy-1,4-naphthoquinone, lawsone) were significant. The anti-inflammatory effect of lawsone (500 $\mathrm{mg} / \mathrm{kg}$ ) was not significantly different from that of the reference drug phenylbutazone $(100 \mathrm{mg} / \mathrm{kg})$ [43]. The antiarthritic potential of aqueous leaf extracts $(50,100$, $250,500,1000,2000 \mathrm{~g} / \mathrm{ml}$ ) was assessed using the \% inhibition of protein denaturation and the membrane lysis method. The aqueous extract showed a dose-dependent antiarthritic effect that is statistically comparable to diclofenac sodium [21, 44].

The anti-inflammatory and analgesic effect of Lawsonia inermis leaves with aqueous extract of Ricinus communis leaves (as a mixture) were tested in induced knee osteoarthritis in rats (which was induced by intraarticular injection of monosodium iodoacetate). After three days of injection, the results demonstrated a substantial reduction in the injected paws' knee joint width and volume, as well as an improvement in gait analyses. In comparison to the vehicle group, mechanical allodynia analysis after 3 weeks, hotplate latency test after 10 days, spontaneous movements after 7 days, and mechanical 
allodynia following two weeks exhibited a substantial analgesic effect. It also shown substantial therapeutic histological alterations in the rats' knees $[21,44]$.

The methanolic leaves extract appeared to reduce the chemically induced nociceptive pain stimuli significantly $(\mathrm{p}<0.01)$ [14]. In acetic acid and heat-induced pain models, methanol, petroleum ether, and ethyl acetate extracts of Lawsonia inermis leaves $(250$ and $500 \mathrm{mg} / \mathrm{kg}$, IP) had a substantial dose-dependent analgesic effect ( $p$ 0.05-0.001) [19]. The tail immersion and hot plate techniques were used to investigate the synergistic analgesic effects of chloroform extracts of Lawsonia inermis leaves and roots tubers and Chlorophytum borivilianum in mice. At a dose of $200 \mathrm{mg} / \mathrm{kg} \mathrm{BW}$, chloroform extracts of both plants exhibited considerable analgesic activity, and the combination of both extracts produced higher analgesic activity than each extract alone [20].

In mice with acetic acid-induced writhing, the ethanolic extracts showed no substantial inhibition $((28.45 \%, \mathrm{p} 0.3)$ of the writhing reflex at a dose of $500 \mathrm{mg} / \mathrm{kg}$ compared to diclofenac sodium that showed inhibition of $82.7 \%$ at a $25 \mathrm{mg} / \mathrm{kg}$ BW [24, 44].

The anti-inflammatory effect of lawsone could be attributed to its inhibitory effect on cyclooxygenases and subsequent inhibition of prostaglandins synthesis [40]. Furthermore, in studying 5- lipoxygenase (5-LOX) inhibition, the methanolic extract exhibited better 5-LOX inhibition than chloroform and hexane extracts of henna seeds, with an IC50 value of $510.23 \mathrm{mg} / \mathrm{l}$ [45].

Study limitations. Following the Guidelines of laboratory animals use and regulations of Thi-Qar University, it was not possible to test more laboratory animals in accordance with The European Council Directive recommendations $(2010 / 63 / \mathrm{EU})$, which is based on the principle of Three Rs, replace, reduce, and refine the use of animals used in scientific research. The authors have to conduct their study using a sample size of 120 mice. Sample size could be increased in future studies to have better insight into the efficacy and safety of lawsone. However, the current study is required to suggest further studies that could help in heightening the medical importance of lawsone.

Prospects for further research. Further studies are required, including conducting a well-controlled study with a larger sample size to determine the therapeutic effect of lawsone in vivo. Also, another study is required to determine the teratogenicity of lawsone before introducing lawsone into clinical trials as analgesic and anti-inflammatory.

\section{Conclusion}

Lawsonia inermis leaves contained $1.2 \%$ of lawsone. The $\mathrm{LD}_{50}$ of the oral lawsone in rats was $96 \mathrm{mg} / \mathrm{kg}$. An $80 \mathrm{mg} / \mathrm{kg}$ was the highest dosage that did not kill any experimental animal. Both lawsone and aspirin possessed analgesic effect compared with control group $(\mathrm{P}<0.0001$ and $\mathrm{P}<0.001$ respectively). However, lawsone induced potent analgesic effect compared with aspirin $(\mathrm{p}<0.1)$. On the other hand, both lawsone and aspirin exert antiinflammatory effect $(\mathrm{p}<0.05)$ compared with control group. They were equipotent in carrageenan induced hind paw oedema. Accordingly, lawsone possesses potent analgesic and anti-inflammatory effects, which endorse the practical medical importance of Lawsonia inermis as analgesic and anti-inflammatory medication.

\section{Conflicts of interest}

The authors declare that they have no conflicts of interest.

\section{Financing}

The study was performed without financial support.

Acknowledgments. The authors like to acknowledge the College of Science, the University of Thi-Qar for their cooperation in providing the experimental animals and the Biology Department-Plant Taxonomy, College of Education, Thi-Qar University, for their assistance in classifying the henna leaves. Their gratitude extends to the College of Medicine, the University of ThiQar, for their support while conducting the study.

\section{References}

1. Badoni Semwal, R., Semwal, D. K., Combrinck, S., Cartwright-Jones, C., Viljoen, A. (2014). Lawsonia inermis L. (henna): Ethnobotanical, phytochemical and pharmacological aspects. Journal of Ethnopharmacology, 155 (1), 80-103. doi: http://doi.org/10.1016/ j.jep.2014.05.042

2. ITIS report, Lawsonia inermis L. Available at: https://www.itis.gov/servlet/SingleRpt/SingleRpt?search_topic= TSN\&search_value=503345\#null

3. Boubaya, A., Marzougui, N., Ben Yahia, L., Ferchichi, A. (2011). Chemical diversity analysis of Tunisian Lawsoniainermis L. populations. African Journal of Biotechnology, 10 (25), 4980-4987. Available at: https://www.ajol.info/index.php/ajb/article/view/94180

4. Shastry, C. S., Kiran, U. P., Aswathanarayana, B. J. (2012). Effect of acute and chronic administration of the aqueous extract of Lawsoniainermis leaves on haloperidol induced catalepsy in albino mice. Research Journal of Pharmaceutical, Biological and Chemical Sciences, 3 (3), 1107-1116. Available at: https://www.rjpbcs.com/pdf/2012_3(3)/[117].pdf

5. Sharma, R. K., Goel, A., Bhatia, A. K. (2016). Antityphoid activity and phytochemical screening of different extracts of L. inermis plant leaves. International Journal of Current Research, 8 (8), 37539-37542. Available at: https://www.journalcra.com/sites/default/ files/issue-pdf/17025.pdf

6. Jabborova, D., Davranov, K., Egamberdieva, D. (2019). Antibacterial, Antifungal, and Antiviral Properties of Medical Plants. Medically Important Plant Biomes: Source of Secondary Metabolites, 51-65. doi: http://doi.org/10.1007/978-981-13-9566-6_3

7. Ibrahim, S. M. S., Rasool, C. S., Al-asady, A. Ab. (2021). Antimicrobial activity of crude henna extract against Grampositive bacteria. Iraq Medical Journal, 5 (3), 89-93. doi: http://doi.org/10.22317/imj.v5i3.1036

8. Badiee, P., Mardani, M., Gharibnavaz, M., Jassebi, A., Jafarian, H., Ghassemi, F. (2018). Comparison of anti-Candida activities of the ancient plants Lawsonia inermis and Ziziphus spina christi with antifungal drugs in Candida species isolated from oral cavity. Journal of Conservative Dentistry, 21 (4), 359-362. doi: http://doi.org/10.4103/jcd.jcd_291_17

9. Gozubuyuk, G. S., Aktas, E., Yigit, N. (2014). An ancient plant Lawsonia inermis (henna): Determination of in vitro antifungal activity against dermatophytes species. Journal de Mycologie Médicale, 24 (4), 313-318. doi: http://doi.org/10.1016/j.mycmed.2014.07.002 
10. Ismail, K. A., Ibrahim, A. N., Ahmed, M. A.-F., Hetta, M. H. (2014). Comparison between the effect of Lawsonia inermis and flubendazole on Strongyloides species using scanning electron microscopy. Journal of Parasitic Diseases, 40 (2), $415-422$. doi: http://doi.org/10.1007/s12639-014-0519-2

11. Motazedian, M. H., Mikaeili, F., Mohebali, M., Miri, R., Habibi, P., Kamarloie, S. (2016). The antileishmanial effects of Lowsonia inermis and Cedrus libani on Leishmania major promastigotes: an in vitro study. Journal of Parasitic Diseases, 41 (2), 375-379. doi: http://doi.org/10.1007/s12639-016-0809-y

12. Singh, A., Singh, D. K. (2001). Molluscicidal activity of Lawsoniainermis and its binary and tertiary combinations with other plant derived molluscicides. Indian Journal of Experimental Biology, 39, 263-268.

13. Elaguel, A., Kallel, I., Gargouri, B., Ben Amor, I., Hadrich, B., Ben Messaoud, E. et. al. (2019). Lawsonia inermis essential oil: extraction optimization by RSM, antioxidant activity, lipid peroxydation and antiproliferative effects. Lipids in Health and Disease, 18 (1). doi: http://doi.org/10.1186/s12944-019-1141-1

14. Hasan, K. M., Yesmin, S., Akhter, S. F., Paul, S., Sarker, S., Islam, A. et. al. (2016). Hepatoprotective potentiality of various fractions of ethanolic extracts of Lawsoniainermis(henna) leaves against chemical-induced hepatitis in rats. Biochemistry and Molecular Biology, 1 (2), 17-22. Available at: https://article.sciencepublishinggroup.com/html/10.11648.j.bmb.20160102.12.html

15. Darvin, S. S., Esakkimuthu, S., Toppo, E., Balakrishna, K., Paulraj, M. G., Pandikumar, P. et. al. (2018). Hepatoprotective effect of lawsone on rifampicin-isoniazid induced hepatotoxicity in in vitro and in vivo models. Environmental Toxicology and Pharmacology, 61, 87-94. doi: http://doi.org/10.1016/j.etap.2018.05.006

16. Hsouna, A. B., Mongi, S., Culioli, G., Blache, Y., Ghlissi, Z., Chaabane, R. et. al. (2013). Protective effects of ethyl acetate fraction of Lawsonia inermis fruits extract against carbon tetrachloride-induced oxidative damage in rat liver. Toxicology and Industrial Health, 32 (4), 694-706. doi: http://doi.org/10.1177/0748233713502839

17. Ahmed, S., Saeed, A., Asadullah, M. (2016). Effectiveness of Lawsonia inermis for psychopharmacological activity on staircase in NMRI mice. Medical Forum, 27 (11), 2-4.

18. Alia, B. H., Bashir, A. K., Tanira, M. O. M. (1995). Anti-Inflammatory, Antipyretic, and Analgesic Effects of Lawsonia inermis L. (Henna) in Rats. Pharmacology, 51 (6), 356-363. doi: http://doi.org/10.1159/000139347

19. Sultana, S., Khosru, K. H. (2011). Analgesic and antidiarrhoeal activity of Lawsoniai nermis. International journal of pharmaceutical sciences and research, 2 (12), 3183-3188. Available at: https://ijpsr.com/bft-article/analgesic-and-antidiarrhoealactivities-of-lawsonia-inermis/

20. Imam, H., Mahbub, N. U., Khan, M. F., Hana, H. K., Sarker, M. M. R. (2013). Alpha Amylase Enzyme Inhibitory and Antiinflammatory Effect of Lawsonia inermis. Pakistan Journal of Biological Sciences, 16 (23), 1796-1800. doi: http://doi.org/10.3923/ pjbs.2013.1796.1800

21. Ziaei, A., Sahranavard, S., Gharagozlou, M. J., Faizi, M. (2016). Preliminary investigation of the effects of topical mixture of Lawsonia inermis L. and Ricinus communis L. leaves extract in treatment of osteoarthritis using MIA model in rats. DARU Journal of Pharmaceutical Sciences, 24 (1). doi: http://doi.org/10.1186/s40199-016-0152-y

22. Rekik, D. M., Ben Khedir, S., Daoud, A., Ksouda Moalla, K., Rebai, T., Sahnoun, Z. (2019). Wound Healing Effect of Lawsonia inermis. Skin Pharmacology and Physiology, 32 (6), 295-306. doi: http://doi.org/10.1159/000501730

23. Yassine, K. A., Houari, H., Mokhtar, B., Karim, A., Hadjer, S., Imane, B. (2020). A topical ointment formulation containing leaves' powder of Lawsonia inermis accelerate excision wound healing in Wistar rats. Veterinary World, 13 (7), 1280-1287. doi: http://doi.org/10.14202/vetworld.2020.1280-1287

24. Hadisi, Z., Nourmohammadi, J., Nassiri, S. M. (2018). The antibacterial and anti-inflammatory investigation of Lawsonia Inermis-gelatin-starch nano-fibrous dressing in burn wound. International Journal of Biological Macromolecules, 107, $2008-2019$. doi: http://doi.org/10.1016/j.ijbiomac.2017.10.061

25. Mikhaeil, B. R., Badria, F. A., Maatooq, G. T., Amer, M. M. A. (2004). Antioxidant and Immunomodulatory Constituents of Henna Leaves. Zeitschrift Für Naturforschung C, 59 (7-8), 468-476. doi: https://doi.org/10.1515/znc-2004-7-803

26. Dikshit, V., Dikshit, J., Saraf, M., Thakur, V., Sainis, K. (2000). Immunomodulatory activity of naphthoquinone fraction of Lawsonia inermis Linn. Phytomedicine (Jena), 7, 102-103.

27. Patel, K. M., Shah, S. K. (2017). Evaluation of antiurolithiatic activity of Lawsonia inermis in rats. International Journal of Pharmaceutical Sciences and Nanotechnology, 10 (3). Available at: https://www.ijpsnonline.com/index.php/ijpsn/article/view/844

28. Kore, K. J., Shete, R. V., Jadhav, P. J., Kabra, M. P. (2011). Antiurolithiatic effects of hydroalcoholic extract of LawsoniainermisL leaves. International Journal of Universal Pharmacy and Life Sciences, 1 (2), 81-95.

29. Singh, S., Verma, N., Karwasra, R., Kalra, P., Kumar, R., Gupta, Y. (2015). Safety and efficacy of hydroalcoholic extract from Lawsonia inermis leaves on lipid profile in alloxan-induced diabetic rats. AYU (An International Quarterly Journal of Research in Ayurveda), 36 (1), 107-112. doi: http://doi.org/10.4103/0974-8520.168999

30. Antika, M. A., Ilyas, S., Sari, M. I. (2017). Effect of Lawsonia inermis Linn. Ethanol Extract on the Superoxyde Dismutase Activity in Hyperglycemic Rattus norvegicus. Indonesian Journal of Medicine, 02 (02), 79-85. doi: http://doi.org/10.26911/ theijmed.2017.02.02.01

31. Goswami, M., Kulshreshtha, M., Rao, C. V., Yadav, S., Yadav, S. (2011). Anti-ulcer potential of LawsoniainermisL leaves against gastric ulcers in rats. Journal of Applied Pharmaceutical Science, 1 (2), 69-72. Available at: https://japsonline.com/admin/php/uploads/23_pdf.pdf

32. Candra, K. R. Y., Sandya, L. S. D., Ruth, S. K., Nagarjuna, S., Padmanabha, R. Y. (2011). Evaluation of diuretic activity of aqueous and ethanolic extracts of Lawsoniainermisleaves in rats. Asian Journal of Plant Science and Research, 1 (3), $28-33$.

33. Abdel-Hamid, N. M., Mohafez, O. M., Nazmy, M. H., Farhan, A., Thabet, K. (2015). The effect of co-administration of Lawsonia inermis extract and octreotide on experimental hepatocellular carcinoma. Environmental Health and Preventive Medicine, 20 (3), 195-203. doi: http://doi.org/10.1007/s12199-015-0451-9

34. Pandey, S., Raja, W. (2020). Antitumoral effect of lawsonia inermis extract on melanoma tumor-bearing C57BL/6 mice. Pharmacognosy Magazine, 16 (70), 435-442. doi: http://doi.org/10.4103/pm.pm_219_19

35. Ozaslan, M., Karagoz, I. D., Lawal, R. A., Kilic, I. H., Cakir, A., Kalender, M. E. et. al. (2009), Antitumoral Effect of L. inermis in Mice with EAC. International Journal of Pharmacology, 4, 263-267. Available at: https://docsdrive.com/pdfs/ansinet/ijp/2009/263-267.pdf

36. Saeed, S. M. G., Sayeed, S. A., Ashraf, S., Naz, S., Siddiqi, R., Mesaik, A. A. (2013). A new method for the isolation and purification of lawsone from Lawsoniainermis and its ROS inhibitory activity. Pakistan Journal of Botany, 45 (4), $1431-1436$. 
37. Al-Ali, A., Alkhawajah, A., Randhawa, M. A., Shaikh, N. A. (2008). Oral and intraperitoneal LD50 of thymoquinone, an active principle of Nigella sativa, in mice and rats. Journal of Ayub Medical College Abbottabad, 20 (2), $25-27$.

38. Raina, A., Chandra, M., Dogra, T., Raj, J., Pahuja, M. (2013). Determination of median lethal dose of combination of endosulfan and cypermethrin in wistar rat. Toxicology International, 20 (1), 1-5. doi: http://doi.org/10.4103/0971-6580.111531

39. Metcalf, C. S., Klein, B. D., McDougle, D. R., Zhang, L., Smith, M. D., Bulaj, G., White, H. S. (2014). Analgesic Properties of a Peripherally Acting and GalR2 Receptor-Preferring Galanin Analog in Inflammatory, Neuropathic, and Acute Pain Models. Journal of Pharmacology and Experimental Therapeutics, 352 (1), 185-193. doi: http://doi.org/10.1124/jpet.114.219063

40. Hashemi, V., Ghanadi, A. R., Mousavi, D. (2000). Analgesic and anti-inflammatory effects to total extract flavonoid fraction and volatile oil of Salvia hydrangea. Journal of Research in Medical Sciences, 5 (2), 10-14.

41. Karawya, M. S., Abdul Wahhab, S. M., Zeki, A. Y. (1969). A study of lawsone content of henna. Lloydia, 32 (1), $76-78$.

42. Humaish, H. H. (2017). Study comparison analgesic, antipyretic and anti-inflammatory activity of aqueous and alcoholic leaves extract ofLawsoniainermis L. (Henna) with ketoprofen in male albino rats. Kufa Journal For Veterinary Medical Sciences, 8 (2), 88-100.

43. Al-snafi, A. E. (2019). A review on Lawsonia inermis: a potential medicinal plant. International Journal of Current Pharmaceutical Research, 11 (5), 1-13. doi: https://doi.org/10.22159/ijcpr.2019v11i5.35695

44. Galehdari, H., Negahdari, S., Kesmati, M., Rezaie, A., Shariati, G. (2016). Effect of the herbal mixture composed of Aloe Vera, Henna, Adiantum capillus-veneris, and Myrrha on wound healing in streptozotocin-induced diabetic rats. BMC Complementary and Alternative Medicine, 16 (1), 386. doi: https://doi.org/10.1186/s12906-016-1359-7

45. Wurm, G., Baumann, J. (1981). Beeinflussung der Prostaglandin-synthesedurch hydroxy-1,4-naphthochinon-derivate. 2. Mitt: Untersuchungen an 1,4-Naphthochinonen. Arzneimittelforschung, 31 (10), 1673-1677.

Received date 08.12.2021

Accepted date 23.02.2022

Published date 28.02.2022

Tayseer Ali Talab, Department of Pharmacology, College of Medicine, University of Thi-Qar, Thi-Qar, ThiQar, Nasiriyah, B O Box 42, Iraq

Narjes Alfuraiji, Department of Pharmacology, College of Medicine, University of Karbala, Karbala, Iraq, 56001

Ali Esmail Al-Snafi*, Department of Pharmacology, College of Medicine, University of Thi-Qar, Thi-Qar, Nasiriyah, B O Box 42, Iraq

*Corresponding author: Ali Esmail Al-Snafi, e-mail: aboahmad61@yahoo.com 